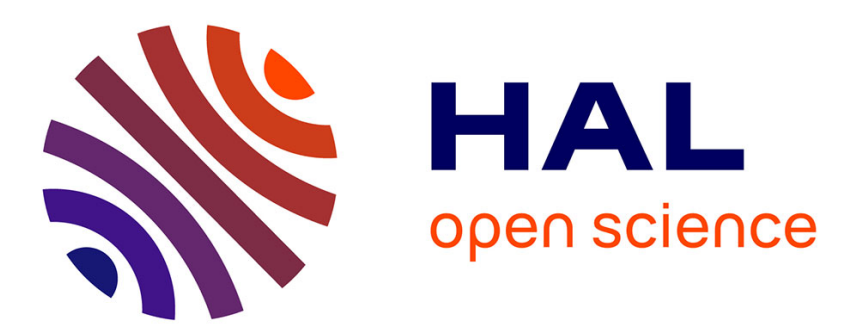

\title{
Understanding the Best Way to Embed ICT in Teacher Education
}

\author{
Amber Mcleod, Kelly Carabott
}

\section{To cite this version:}

Amber Mcleod, Kelly Carabott. Understanding the Best Way to Embed ICT in Teacher Education. 11th IFIP World Conference on Computers in Education (WCCE), Jul 2017, Dublin, Ireland. pp.366375, 10.1007/978-3-319-74310-3_38. hal-01762897

\section{HAL Id: hal-01762897 https://hal.inria.fr/hal-01762897}

Submitted on 10 Apr 2018

HAL is a multi-disciplinary open access archive for the deposit and dissemination of scientific research documents, whether they are published or not. The documents may come from teaching and research institutions in France or abroad, or from public or private research centers.
L'archive ouverte pluridisciplinaire HAL, est destinée au dépôt et à la diffusion de documents scientifiques de niveau recherche, publiés ou non, émanant des établissements d'enseignement et de recherche français ou étrangers, des laboratoires publics ou privés. 


\title{
Understanding the Best Way to Embed ICT in Teacher Education
}

\author{
Amber McLeod and Kelly Carabott \\ Monash University, Clayton, VIC 3800, Australia
}

\begin{abstract}
Every Australian school teacher is required to include instruction in information and communication technology (ICT) in their teaching. Thus, ICT in education, including technological, pedagogical and content knowledge (TPACK), needs to be taught to every pre-service teacher (PST). A drop in the digital competence of high school students suggests many PSTs may not be reaching the levels of ICT competence envisaged to deliver the Australian Curriculum. Universities are grappling with the most effective way to address this. This paper focuses on the effectiveness of embedding ICT in education units in two different ways. Qualitative data was collected from PSTs from units in which ICT was actively embedded: in one, ICT was embedded as a content delivery tool only; in the other, PSTs were additionally required to create a digital learning object as part of the assessment task employing experiential learning. Findings indicate that when PSTs are required to create using digital technologies they gain a deeper understanding of TPACK and have greater intention to use ICT in their future classrooms.
\end{abstract}

Keywords. Computers and Society · Initial teacher education · Information and Communication Technology $\cdot$ Experiential learning

\section{Introduction}

Although included in the Australian Curriculum [1], many students leave school without achieving the minimum level of digital competence deemed acceptable [2]. This suggests that digital technologies are not always taught effectively. Therefore, the ways PSTs are taught ICT requires examination.

In Australia, education degrees can gain accreditation by stating that ICT is embedded within their units. It is unclear, however, whether current methods of embedding are effective. In this paper, we explore two different methods of embedding ICT in education units to show the effectiveness of each approach.

\section{Context}

ICT is taught to Australian school students in two ways [1]. First, there is a dedicated technologies learning area made up of two strands: design and technologies and digital technologies. Second, the focus of this paper, ICT is a general capability, to be embedded across disciplines which all teachers are expected to incorporate in their 
lessons. In addition, the Australian Professional Standards for Teachers [3] mentions ICT explicitly in three standards and has implications for the others:

Standard 1. Know students and how they learn.

Standard 2. Know the content and how to teach it.

2.6 ICT: Implement teaching strategies for using ICT to expand curriculum learning opportunities for students.

Standard 3. Plan for and implement effective teaching and learning.

3.4 Select and use resources: Demonstrate knowledge of a range of resources, including ICT, that engage students in their learning.

Standard 4. Create and maintain supportive and safe learning environments.

4.5 Use ICT safely, responsibly, and ethically.

Standard 5. Assess, provide feedback and report on student learning.

Standard 6. Engage in professional learning.

Standard 7. Engage professionally with colleagues, parents/carers and the community [3].

The most recent results of the Australian National Assessment Program indicate that the percentage of Year 10 students reaching proficiency level for digital technologies is concerningly low (52\%), and show a statistically significant drop in digital competence across all cohorts of students [2]. These results indicate that teachers are ill equipped to teach ICT to the level required; and that students entering university cannot be assumed to have a proficient level of digital competence, in other words, digital competence should be addressed in education degrees.

The idea of the 'digital native' [4] persists in universities, evidenced by the push to move education into online environments, but while technology is embedded in young people's lives, their skills are not uniform and they use a limited range of established technologies [5,6]. It is unsurprising then, that PSTs are not reaching the level of digital competence expected [7,8]; education degrees should ensure this.

The TPACK model [9], an essential part of ICT, suggests that teachers need an understanding of Content Knowledge (CK), Pedagogical Knowledge (PK) and Technological Knowledge (TK) in order to effectively incorporate technology. It appears that many education degrees do not explicitly address ICT $[10,11]$. While some degrees include a technology unit $[12,13]$, they may not adequately prepare PSTs for the complexities involved in integrating ICT in lessons [14]. Many universities embed ICT with varying degrees of effectiveness [11] and methods units often have almost no technology [12]. If education degrees are not designed to have a strong influence on how PSTs use technology graduate teachers may be unable to deliver the digital technology components of the curriculum as envisaged.

Where ICT is embedded, the digital competence, interest and time constraints of each academic influence the extent. PSTs suggested little was done to help them understand how ICT could facilitate their own teaching or teaching of their subject in their education degrees and 9\% did not believe their lecturers embedded ICT at all; only $26 \%$ believing their education lecturers modelled ICT well $[15,16]$. Successfully incorporating ICT into education degrees requires PSTs to not only understand why ICT could be used to support learning and teaching across the curriculum, but to also experience this (17). However, many teacher educators lack this knowledge and experience themselves (17). Current embedding practices, which range from a 
transmission lecture approach (didactic) to a combination of transmission and hands on (constructive) learning, fall short of the results expected of a more experiential approach. This research explores how such an approach could more effectively incorporate ICT, including TPACK, into education units.

Kolb's experiential learning cycle involves forming abstract concepts, testing them in new situations, a concrete experience, and observation and reflection, which is then used to form further abstract concepts [18]. Experiential learning allows students to apply the knowledge or conceptual understanding gained to real world problems. When the relevance of the experience is revealed, motivation, self-direction and organisation are increased allowing students to more effectively integrate new material with prior knowledge [19]. Students are able to learn at their own pace or level, allowing differentiated learning [20] which is particularly important in digital competence as PSTs arrive at university with varying levels of digital competence.

In this paper, which seeks to add to the data on the most effective method, we compare traditional and experiential learning methods of embedding ICT.

\section{Methodology}

This study was conducted using qualitative methods: focus groups and written reflections to compare two different methods of embedding ICT including TPACK knowledge in university units. The research questions that guided the study were:

1. Is there evidence of improved confidence with ICT (TK)?

2. Is there evidence of increased understanding of the pedagogical implications of using ICT (PK)?

3. Is there evidence of increased understanding of the ICT requirements for teachers (CK)?

4. Is there evidence of an increased likelihood of PSTs using digital technology in the future?

\subsection{Participants}

Data collected in 2016-17, as described in table 1, was thematically analysed. 
Table 1. Description of cohorts and data collection.

\begin{tabular}{|c|c|c|c|}
\hline & $\begin{array}{c}\text { Cohort } 1 \\
\end{array}$ & Cohort 2 & Cohort 3 \\
\hline $\begin{array}{l}\text { Pedagogical } \\
\text { approach }\end{array}$ & $\begin{array}{l}\text { ICT in lectures and } \\
\text { tutorials only. }\end{array}$ & \multicolumn{2}{|c|}{$\begin{array}{c}\text { ICT embedded in lectures, } \\
\text { tutorials and assessment. }\end{array}$} \\
\hline Participants & $\begin{array}{l}71^{\text {st }} \text { yr PSTs } \\
\text { undergraduate }\end{array}$ & $\begin{array}{l}284^{\text {th }} \text { yr PSTs } \\
\text { undergraduate }\end{array}$ & $\begin{array}{l}361^{\text {st }} \text { yr PSTs } \\
\text { postgraduate }\end{array}$ \\
\hline $\begin{array}{l}\text { Unit } \\
\text { description }\end{array}$ & $\begin{array}{l}\text { Learning in a } \\
\text { university context. }\end{array}$ & $\begin{array}{l}\text { Practical } \\
\text { Education. }\end{array}$ & $\begin{array}{l}\text { Arts, design \& health } \\
\text { education. }\end{array}$ \\
\hline & Cohort 1 & Cohort 2 & Cohort 3 \\
\hline $\begin{array}{l}\text { ICT used for } \\
\text { unit }\end{array}$ & $\begin{array}{l}\text { Prezi, PowerPoint, } \\
\text { Moodle, Zaption, } \\
\text { Zeetings, Kahoot, Poll } \\
\text { everywhere, Padlet, } \\
\text { easel.ly, Quizlet live, } \\
\text { Monash library, Google } \\
\text { Scholar, Flipquiz. }\end{array}$ & $\begin{array}{l}\text { Kahoot, Powtoon, } \\
\text { Emaze, PowerPoint } \\
\text { Moodle, YouTube, } \\
\text { Aurasma, iPads, Sock } \\
\text { puppets, Geocaching, } \\
\text { Pokemon Go. }\end{array}$ & $\begin{array}{l}\text { Socrative, Quizalize, } \\
\text { PowerPoint, YouTube, } \\
\text { Prezi, websites, } \\
\text { Socrative, Quizalize, } \\
\text { Audacity, Sphero, Ollie, } \\
\text { coding applications, } \\
\text { Google docs, Padlet. }\end{array}$ \\
\hline $\begin{array}{l}\text { ICT content } \\
\text { discussed }\end{array}$ & $\begin{array}{l}\text { The importance of } \\
\text { digital competence at } \\
\text { university and in } \\
\text { education. }\end{array}$ & $\begin{array}{l}\text { Digital competence, } \\
\text { SAMR, TPACK, } \\
\text { binary code. }\end{array}$ & $\begin{array}{l}\text { ICT curriculum, digital } \\
\text { competence, experiential } \\
\text { learning, maker spaces. }\end{array}$ \\
\hline $\begin{array}{l}\text { ICT required } \\
\text { for } \\
\text { assessment: }\end{array}$ & & \multicolumn{2}{|c|}{$\begin{array}{l}50 \% \text { of grade. Groups create \& present digital } \\
\text { resource. A few instructional videos were } \\
\text { provided, but digital platforms not specified } \\
\text { because of transient nature of digital technology, } \\
\text { selecting and learning to use ICT individually was } \\
\text { an intended part of skills development. }\end{array}$} \\
\hline $\begin{array}{l}\text { Data } \\
\text { collection and } \\
\text { analysis }\end{array}$ & $\begin{array}{l}\text { Focus groups recorded } \\
\text { and transcribed. }\end{array}$ & PSTs wrote a & rsonal reflection. \\
\hline
\end{tabular}

\section{Results and Discussion}

The data and discussion of the data will be presented together in this section.

\subsection{Is there evidence of improved confidence with ICT (TK)?}

Cohort 1: A surprising majority of Cohort 1, who had completed school within the last two years, indicated that they did not have a lot of experience using digital technologies at school. Also, while they had been encouraged to use digital technology at university, exposed to a number of new digital technologies in this particular unit and now felt more confident with those programs and platforms, they did not feel that their ICT skills had been increased through participation in the unit. Rather, they had gained a better understanding of the digital technologies they liked and did not like. An exception was increased confidence in using digital technologies such as Google Scholar or the Library Website to research their assignments. PSTs did suggest that being shown and given the opportunity to play with programs in this unit made them more likely to use them in the future, as opposed to other units where: 
Some of my [lecturers] just said, 'Oh this is a good website you can use it' but they haven't shown us at all, I don't remember any of them (Cohort 1).

One PST, who rated her ICT skills as $2 / 10$, suggested that she would only use a program if she was forced to for an assessment, as she had for a YouTube assignment.

Cohorts 2 and 3: While a number of PSTs found that their ICT skills were improved through the assignment, others who had perhaps overestimated their ability, realised that digital technologies were not as simple as many had thought, with a number of comments on the time and work involved in the assignment. For example:

Creating this digital resource has given me an insight into the effort,

time and technological knowledge that is needed to develop such a resource (Cohort 3).

It seems that PSTs who only used ICT in class were presented with the option of engaging in an essentially passive way. This resulted in little change in their technological knowledge and competence. However, when required to actively engage with ICT for their assessment, PSTs extended their abilities, increasing digital competence. Students noted that participation in the experiential learning cycle as part of their assessment proved to be challenging, but ultimately rewarding.

\subsection{Is there evidence of increased understanding of the pedagogical implications of using ICT (PK)?}

Cohort 1: When asked their opinions of the ICT they had used in the unit and if they would use them in their own teaching, there was surprisingly little enthusiasm. PSTs indicated that they could not see the "academic" value of using the programs, except as games or gimmicks to motivate students. The PSTs acknowledged that the colours, music, and fun layout of the programs encouraged them to engage with the content in a way that pen and paper would not. Anonymity, allowing students to be wrong without embarrassment, being able to work at your own pace, and instant feedback were cited as benefits to using many of the programs. PSTs were critical of other aspects, such as timers, which may stress students. This shows they were beginning to develop a pedagogical understanding of how ICT may influence learning.

Interestingly, PSTs had difficulty imagining using the programs in other settings. While they could all appreciate the use of the programs for the final years of school, few thought they would be appropriate for younger children, believing that the programs were not structured enough, giving students the opportunity to misbehave in class; that use of the programs required a level of thinking which primary students would not be capable of; and that it is more important for young students to develop "practical skills” such as reading books or writing. Typical comments included:

Padlet generates deep thought you wouldn't find in primary school - you don't need in-depth in primary school.

In addition, there was concern that even at the upper levels of high school, there was too much emphasis on technology and other skills were being neglected, as illustrated in this comment about a final year school student:

I knew a friend that was always on laptops ...she suffered because she couldn't write fast enough ... Using technology should be [limited] because having other skills like handwriting are important (Cohort 1). 
PSTs recognised tasks at the substitution level of the SAMR model even though they had not been introduced to the model. They suggested that using programs such as Word to do their assignments was no different to using pen and paper.

Cohorts 2 and 3: PSTs suggested that creating a digital object as an assessment task helped them understand the problems their own students may face, for example:

Working on our resource gave me a student's perspective. Although I have been a student for the last four years, this felt like the first time I compared my own feelings to what student thoughts might be (Cohort 2).

A number of PSTs noted that the opportunity to put theory into practice helped them understand the theory in more depth, it had also changed their attitudes about using digital technology in the classroom as they realised the learning opportunities digital technologies allow if used well, with particular reference to the SAMR model, Bloom's taxonomy and practical or experiential learning pedagogy. They gained a better understanding of how digital technologies could transform education.

While I am confident in using ICT, I don't automatically include it in my lessons - in fact in the past I have struggled to find interesting and relevant ways in which to do so. I have been reluctant to use ICT just for 'the sake of it'. Being exposed to the SAMR model and having an opportunity to put it into practice has helped me significantly in understanding how ICT may be used effectively in the classroom... Previously I had not realised how ICT may assist in encouraging students to a deeper level of thinking, I had seen it purely as a superficial engagement tool (Cohort 2).

The contrast in comments about the pedagogical value of digital technology in the classroom between those PSTs who did not use digital technology in their assessment with those that did, is striking. Cohort 1 had difficulty viewing digital technology as anything more than a substitutional level tool to be used to motivate higher level students. Cohorts 2 and 3, after being placed in the position of learners themselves, realised the level of thinking and engagement required in order to create a digital object was deeper than expected. In addition, as they were required to evaluate the level of their resource on the SAMR scale, the advantages and possibilities of digital technology in education became easier to imagine.

\subsection{Is there evidence of increased understanding of the ICT requirements for teachers $(\mathrm{CK})$ ?}

Cohort 1: The majority of PSTs felt surprised at the amount of digital technology used in the education degree and indicated that they were worried about using digital technologies at schools. In this, their first year of the education degree:

It's been drummed into us; it's going to be a really big thing at school

(Cohort 1).

As the majority of PSTs had not had significant experience with digital technology at school themselves, many suggested they would "wait and see" which technologies schools were using and then learn those, rather than forming their own ideas.

Three students were surprised at the educational technology tools available, as they had not been exposed to them in their own education, and suggested that perhaps teachers were unaware of what was available, for example: 
I found it shocking that it's not... made available to teachers or advertised. I would assume a lot of teachers wouldn't know about that. It isn't broadcast.

Cohorts 2 and 3: Cohort 2 related the assignment to the teacher standards although no specific standard was suggested. While many related the assignment to the standards specifically mentioning ICT, a number indicated that this assignment had developed in them a better understanding of the Teacher Standards, for example:

I had not realised how frequently ICT was included in the AITSL standards. This emphasis on ICT reminds me of the significance of using such technology in the classroom, as well as how it may be used - as a resource to teach content knowledge or discipline-specific skills, or to teach the importance of safe ICT use (Cohort 2, Standard 1.2: Understand how student learn).

I was thinking about the elements of redefinition that our task encompassed, it actually brought to mind the idea that ICT could be used as a platform for involving parents and carers in the educative experience of my students (Cohort 2, Standard 3.7: Engage parents / carers in the educative process).

Cohort 3 reflected upon whether creating a digital presentation had helped them engage more deeply with the unit content, which had a focus on the ICT general capability. Through examination of the PSTs digital storyboards and their reflections, it became evident that the assessment task had increased understanding of how digital technology is integrated throughout the curriculum. PSTs showed a more explicit understanding of the links between curriculum and the use of digital technology to support student outcomes.

While Cohort 1 were aware that digital technologies were important in schools, they were unsure of what they would be required to know or do, suggesting instead that they intended to take their cues from more experienced teachers, perpetuating the existing use of digital technology at school. Cohorts 2 and 3 were much more aware of the digital technology requirements and could see valid pedagogical reasons for their inclusion in the teacher standards and the Australian Curriculum.

\subsection{Is there evidence of an increased likelihood of PSTs using digital technology in the future?}

Cohort 1: While Cohort 1 were not as enthusiastic as expected about the technology used in the unit, after a hands on experience with a program they were impressed by, they indicated a willingness to use it in their own teaching, for example:

I feel more comfortable integrating it into a classroom now that I've used it personally and learned from them rather than had you just thrown them at me Week 1 Semester 1 and said "use these" (Cohort 1).

Cohorts 2 and 3: Reflections indicated that almost all PSTs felt better prepared to use digital technologies in their own classroom, with many excited at the idea.

I will continue to use the SAMR model in conjunction with my students' needs and interests, and the curriculum to assess and guide my decisions in the type of ICT I use in the classroom (Cohort 2).

This task has taught me a variety of knowledge and skills which I see myself implementing in my own future classroom... I was quite nervous 
being creative about my lessons, especially whist on placements where I found most teachers taught through textbooks. Once developing a deeper understanding, I gained confidence in myself and my ability to create lessons that are practical yet engaging for students (Cohort 2).

All cohorts appeared to understand that they will be required to use ICT in their teaching, however, those cohorts who had created a digital object as part of their assessment seemed more eager to incorporate digital technologies in their lessons. After being learners themselves, students had a deeper appreciation of the pedagogical, technological and content learning involved in creating their objects.

\subsection{Other findings}

Although beyond the expectations of this study, there was evidence that some students in Cohort 2 were moving towards a tentative understanding of the TPACK model as illustrated by comments such as the following:

By co-creating a digital timeline about the events of WW2, I learnt an incredible amount about this period in history. In spite of the fact that I am a ... history buff, and ... quite well read on the topic. As such, my eyes have been well and truly opened to the learning potential that exists when students are asked to create their own digital resources. Further, I believe that the creativity and freedom involved must have a positive impact on student engagement. As a teacher, if I were to ask my students to create a digital educational resource addressing a particular curriculum history indepth study, I would be confident that they would be engaged in the task and effectively learning not only content knowledge, but practical history skills (such as research methodology, critical thinking and analysis) and ICT skills (such as responsible use of ICT, resource-checking and understanding how to imbed files in a document or presentation).

As Cohort 2 were students in their fourth and final year of an undergraduate education degree, their pedagogical and content knowledge would have been considerably more advanced than the other two cohorts, both in first year.

\section{Limitations and Challenges}

This study compared cohorts from the first year and final year of their degrees. As such, pedagogical understandings and content knowledge or professional expectations may well have been significantly different. In addition, participants were not separated by age or degree (postgraduates or undergraduate) and so increased technological ability which may have developed beyond high school level through work or other study was not taken into consideration. The authors stress that this is an initial investigation into the efficacy of different methods of embedding which will be extended to include a wide cross section of PSTs.

A challenge was that the effectiveness of embedding ICT in tutorials relied heavily on the students' willingness to engage in the tutorial. 


\section{Conclusion}

The complexity of ICT integration in an Australian teacher education program is highlighted in this study where responsibility to design units that optimize PST readiness for the workplace is emphasized. While the most effective method of embedding digital content in education units is not yet clear, the importance of using considered pedagogical practice when educating PSTs to exploit technology appropriately in their teaching is. The findings suggest that when experiential learning using digital technology for assessment is used in addition to active embedding, PSTs are more likely to understand ICT (and TPACK). A greater intention to use digital technology in education was developed and PSTs began to see beyond its superficial ICT, enabling them to engage in a deeper, experiential evaluation of ICT for learning.

While opportunities to participate in digital tasks were modelled and presented to all cohorts through delivery of content in tutorials and lectures, we believe there are two reasons why Cohorts 2 and 3 appeared to gain a greater understanding of the role of digital technology in education than Cohort 1. First, the assessment task was compulsory for their university qualification. The value of participation in assessment tasks was therefore much higher than in tutorial activities, leading to motivation to engage, problem solve, and use self-directed learning to produce an artefact of high quality. While not all PSTs participated in the tutorial tasks, all Cohort 2 and 3 PSTs participated in the assessment. Second, participation in experiential learning, where time is available to experiment, reflect and form new ideas, may lead to a deeper understanding than participation in a 50-minute tutorial activity. PSTs were required to put themselves in their learner's shoes, step outside their comfort zone to create, reflect and problem-solve using digital technology as the basis.

The findings from this study are relevant for those involved in both module design and development of assessment criteria, as well as stakeholders in all levels of education. Further investigation into the most effective ways to embed ICT to gain a more nuanced understanding of the complexities involved include a focus on assessment tasks, including a wider range of education units, which aspects of ICT and TPACK are being covered, and the ICT knowledge of academics.

\section{References}

1. Australian Curriculum, Assessment and Reporting Authority: General Capabilities (2016)

2. National Assessment Program: 2014 NAP ICTL public report (2014)

3. Australian Institute for teaching and School Leadership. National professional standards for teachers: ICT statements for graduate standards (2014)

4. Prensky, M. Digital natives, digital immigrants. On the Horizon 9(5), 1-6 (2001)

5. Jones, C., Ramanau, R., Cross, S., \& Healing, G. Net generation or Digital Natives: Is there a distinct new generation entering university? Computers \& Education 54(3), 722732 (2010)

6. Margaryan, A., Littlejohn, A., \& Vojt, G. Are digital natives a myth or reality? University students' use of digital technologies. Computers \& Education 56(2), 429-440 (2011)

7. Sánchez, J., Salinas, A., Contreras, D., \& Meyer, E. Does the new digital generation of learners exist? A qualitative study. British J. Ed. Tech. 42(4), 543-556 (2011) 
8. Duncan-Howell, J. Digital mismatch: Expectations and realities of digital competency amongst pre-service education students. Australasian J. Ed. Tech. 28(5), 827-840 (2012)

9. Mishra, P. \& Koehler, M. Technological pedagogical content knowledge: A framework for teacher knowledge. Teachers College Record 108(6), 1017-1054 (2006)

10. Banas, J. R., \& York, C. S. Authentic learning exercises as a means to influence preservice teachers' technology integration self-efficacy and intentions to integrate technology. Australasian J. Ed. Tech. 30(6), 728-746 (2014)

11. Murray, M. C., \& Pérez, J. Unraveling the digital literacy paradox: How higher education fails at the fourth literacy (2014)

12. Brown, D., \& Warschauer, M. From the university to the elementary classroom: Students' experiences in learning to integrate technology in instruction. Journal of Technology and Teacher Education 14(3), 599 - 621 (2006)

13. Hsu, P. S., \& Sharma, P. A systemic plan of technology integration. Educational Technology \& Society, 9(4), 173-184 (2006)

14. Lawless, K. A., \& Pellegrino, J. W. Professional development in integrating technology into teaching and learning: Knowns, unknowns, and ways to pursue better questions and answers. Review of educational research, 77(4), 575-614 (2007)

15. Black, G. \& Smith, K. Hot Topic: ICT in pre-service teacher training. Strategic ICT Advisory Service (2009)

16. Lei, J. Digital natives as preservice teachers: What technology preparation is needed? Journal of Computing in Teacher Education, 25(3), 87-97 (2009)

17. Tondeur, Jo, Roblin, Natalie Pareja, Van Braak, Johan, Fisser, Petra, \& Voogt, Joke. (2013). Technological Pedagogical Content Knowledge in Teacher Education: In Search of a New Curriculum. Educational Studies, 39(2), 239-243.

18. Kolb, D. A. Experiential learning experience as a source of learning and development. New Jersey: Prentice Hall (1984)

19. Weinberg, A., Basile, C., \& Albright, L. The Effect of an Experiential Learning Program on Middle School Students' Motivation Toward Mathematics and Science. Research in Middle Level Education, 35(3), 1-12 (2011)

20. Beard, C. M., \& Wilson, J. P. Experiential learning: A best practice handbook for educators and trainers. Kogan Page Publishers (2006) 